Tetsuya Yokota MD, Kiyoshi Uehara MD, Yukiko Nomoto MD

\title{
Intrathecal morphine suppresses NK cell activity following abdominal surgery
}

Purpose: The effects of morphine on natural killer (NK) cell activity were investigated in patients who underwent hysterectomy.

Methods: Forty patients were divided into four groups of ten. The groups received intrathecal $0.5 \mathrm{mg}$ morphine (Group IT 0.5 ), intrathecal $0.1 \mathrm{mg}$ morphine (Group IT 0.1 ) or $10 \mathrm{mg}$ morphine iv (Group IV). The remaining ten patients served as controls and received inhalation anesthesia alone (Group C). Blood samples were withdrawn before and two hours after surgery and on postoperative days one and two to determine the blood NK cell activity using a chromium release assay with $\mathrm{K} 562$ cells as targets, plasma catecholamines and cortisol levels. The postoperative pain score and side effects were studied in the four groups.

Results: In Group IT 0.5 , the NK cell activity was lower on postoperative day I $(23.9 \pm 8.4 \%)$ than the baseline level (45.7 \pm 13\%) before surgery, and recovered on postoperative day 2. In Groups IT 0.1 , C and IV, the NK cell activities showed no significant changes. In all four groups, neither plasma adrenaline nor noradrenaline concentrations changed. In all four groups, the plasma cortisol levels increased after surgery, on postoperative days I and 2. The pain score was lower two hours after surgery and on postoperative day I in Group IT 0.5 than in the other groups.

Conclusion: These results suggest that long-lasting analgesic effects of intrathecal $0.5 \mathrm{mg}$ morphine suppress the immune response following abdominal surgery.

Objectif : Les effets de la morphine sur l'activité des cellules tueuses naturelles (NK) a été examinée chez des patientes qui devaient subir une hystérectomie.

Méthode : Quarante patientes ont été réparties en quatre groupes de dix. Elles ont reçu 0,5 mg de morphine en administration intrathécale (Groupe IT ${ }_{0.5}$ ), ou 0, I mg de morphine intrathécale (Groupe IT $T_{0.1}$ ) ou $10 \mathrm{mg}$ de morphine iv (Groupe IV). Les dix dernières patientes ont constitué le groupe témoin et n'ont reçu qu'une anesthésie par inhalation (Groupe T). Les prélèvements sanguins ont eu lieu avant l'intervention et deux heures après, et les premier et deuxième jours postopératoires afin de déterminer l'activité sanguine des cellules NK, en utilisant un dosage de la libération de chrome avec des cellules K562 comme cibles, les niveaux plasmatiques de catécholamines et de cortisol. Les scores de douleur postopératoire et les effets secondaires ont été étudiés chez toutes les patientes.

Résultats : Dans le Groupe $\mathrm{IT}_{0.5}$, l'activité des cellules NK a été plus faible au premier jour postopératoire (23,984 \%) qu'au niveau de base (45,7/3\%) déterminé avant l'opération, mais a retrouvé cette valeur au jour 2. Dans les Groupes IT $T_{0,1}$, T et IV, l'activité des cellules NK n'a pas été modifiée de façon significative. Dans les quatre groupes, les concentrations plasmatiques d'adrénaline ou de noradrénaline n'ont pas changé et les niveaux de cortisol plasmatique se sont accrus après l'opération aux jours I et 2. Le score de douleur a été plus bas dans le Groupe IT $T_{0.5}$ que dans les autres groupes, deux heures après l'intervention et au jour I postopératoire.

Conclusion: Ces résultats suggèrent que les effets analgésiques de longue durée de la morphine à $0,5 \mathrm{mg}$, en administration intrathécale, suppriment la réponse immune à la suite d'une intervention chirurgicale abdominale.

From the Department of Anaesthesiology, Kanto Rohsai Hospital, 2035 Kizukisumiyoshi-cho, Nakahara-ku, Kawasaki, Kanagawa 211, Japan. Phone: 81-44-411-3131; Fax: 81-44-433-3150

Address correspondence to: Dr. Tetsuya Yokota

Accepted for publication December 20, 1999. 
M

ORPHINE has been used widely to alleviate various types of pain and to supplement general anesthesia. Since intrathecal administration of morphine was reported by Wang in $1979,{ }^{1}$ many studies on the effects of intrathecal or epidural morphine for postoperative analgesia have been reported. On the other hand, morphine has been reported to possess some immunosuppressive effects. ${ }^{2}$ If immunity is suppressed in patients who have undergone operation, it may make them vulnerable to postoperative infection. Postoperative immunity is also important in conjunction with defence against malignant tumour.

Natural Killer cells, because of their unique ability to recognize and kill tumour cells without processing tumour specific antigen, are thought to form a primary immune defence mechanism against the development of tumours and have a secondary role in defence against tumour metastases. In order to evaluate the effects of intrathecal and intravenous doses of morphine on the immune process of surgery, we investigated NK cell activity, using an immunological tests, in patients undergoing hysterectomy for uterine myoma.

\section{Methods}

After giving informed consent, 40 ASAl patients undergoing elective hysterectomy for uterine myoma and met no history of opioid treatment and immunologic deficiency, were included. They were divided randomly into four groups before surgery. Ten patients, Group $\mathrm{IT}_{0.5}$, received intrathecal $0.5 \mathrm{mg}$ morphine dissolved in $5 \mathrm{ml}$ of physiological saline through a spinal needle inserted into the $\mathrm{L}_{3-4}$ before induction of general anesthesia. Ten patients, Group $\mathrm{IT}_{0.1}$, received intrathecal $0.1 \mathrm{mg}$ morphine and ten patients, Group IV, received $10 \mathrm{mg}$ morphine iv before induction of general anesthesia. Ten control patients, Group C, did not receive morphine.

General anesthesia was induced with $5 \mathrm{mg} \cdot \mathrm{kg}^{-1}$ thiamylal followed by $0.12 \mathrm{mg} \cdot \mathrm{kg}^{-1}$ vecuronium for muscle relaxation and, after tracheal intubation, anesthesia was maintained with isoflurane $0.6-1.5 \%$ and nitrous-oxide $66 \%$ in oxygen. Vecuronium was given as needed during surgery. None of the patients received blood transfusion.

Before surgery around 9 a.m. for a baseline value, two hours after surgery and on postoperative days 1 and 2 , blood samples were withdrawn to determine blood NK cell activity, plasma noradrenaline, adrenaline and cortisol concentrations.

Natural Killer cell activity was measured against K562 target cells in a chromium- $51\left({ }^{5} \mathrm{l} C r\right)$ release assay. 5 Chromium-labeled target cells, $5 \times 10^{3}$, of the human erythroleukemic cell line K-562 were mixed with different concentrations of mononuclear cells from blood samples of the patients, for use as effector cells, to obtain effector to target cell ratios 100:1, 50:1, 25:1 and 12:1. Cell suspensions were incubated for four hours at $37^{\circ} \mathrm{C}$ in humidified air and carbon dioxide $5 \%$. After incubation, the radioactivity of $100 \mu \mathrm{l}$ of cell-free supernatant was counted with an automatic well-type gamma scintillation counter. Percentage cytotoxicity was computed from the formula:

$\%$ activity $=\underline{\left(\text { experimental }{ }^{5 \mathrm{l}} \mathrm{Cr} \text { release }- \text { spontaneous }{ }^{5 \mathrm{l}} \mathrm{Cr} \text { release }\right)} \times 100$ (maximum ${ }^{5} \mathrm{C} \mathrm{Cr}$ release - spontaneous ${ }^{5} \mathrm{C}$ r release)

Spontaneous ${ }^{5} \mathrm{C} C$ release was measured by incubating target cells with assay medium, and maximum release was measured by incubating target cells in water containing sodium sulphate $5 \%$. The values of spontaneous release were in the range of $5 \%-10 \%$ of the maximal release in all experiments. Maximal release was always greater than $5.0 \times 10^{3} \mathrm{cpm} \cdot 10^{-4}$ cells.

Plasma concentrations of adrenaline and noradrenaline were measured by high pressure liquid chromatography. Serum cortisol was measured by radioimmunoassay.

After recovery from general anesthesia, pain score and side effects were examined. Postoperative pain was assessed by one of three observers who was unaware of the dose of morphine used after questioning the patient and asking them to breathe deeply, cough, and move about. It was rated on a scale of 0 to 4 (0; pain free with movement or coughing, 1 ; minimal discomfort on movement or coughing, 2; comfortable at rest, moderate pain on movement or coughing, 3; discomfort at rest, considerable pain with movement or coughing, 4; severe pain, even at rest.) according to the pain rating. Supplemental analgesia was limited to non-steroidal antiinflammatory drugs such as diclofenac sodium and indomethacin: opioids were not used. The side effects were examined about respiratory depression, nausea, vomiting, pruritus and hypotension. Respiratory depression was defined as respiratory frequency of less than $10 \mathrm{bpm}$ and hypotension was defined as decrease in systolic arterial pressure of at least $20 \mathrm{mmHg}$.

Statistical comparisons were made by non-parametric methods with Wilcoxon matched, pairs signed ranks test for paired data, and Mann-Whitney Test for unpaired data. $P<0.05$ was considered statistically significant. Values are presented as the means \pm SD . 
Results

\section{Patient background}

The four groups of patients were not different from each other in terms of age, body weight, duration of surgery and volume of bleeding. (Table I)

\section{Pain score}

Pain scores were lower two hours after surgery in Group $\operatorname{IT}_{0.5}(2.1 \pm 0.3)$ and Group $\operatorname{IT}_{0.1}(2.4 \pm 0.2)$ than in Groups $\mathrm{C}(3.4 \pm 0.2)$ and IV $(3.4 \pm 0.2)$. On postoperative day 1 , the pain score was lower in Group $\operatorname{IT}_{0.5}(1.8 \pm 0.2)$ than in Group C $(2.4 \pm 0.2)$ and $\operatorname{IV}(2.3 \pm 0.2)$. (Mean \pm SD) $P<0.05$. (Figure 1 )

In Groups C, IV and IT $_{0.1}$, two to five patients required postoperative non-steroidal antiinflammatory drugs analgesia and in Group $\mathrm{IT}_{0.5}$, one to two patients required.

\section{Side effects}

Nausea occurred in one or two patients in each group without differences among groups. Itching occurred in one patient in each of the three groups receiving morphine. Neither respiratory depression nor hypotension occurred in any group. Postoperative infection did not occur in any group. (Table II)

\section{NK cell activity}

The NK cell activity showed no changes in Groups $\mathrm{IT}_{0.1}, \mathrm{C}$ and IV. In Group $\mathrm{IT}_{0.3} \mathrm{NK}$ cell activity was

TABLE I Patient data

\begin{tabular}{lllll}
\hline & Group C & Group IV & Group IT $_{0.1}$ & Group $I_{0.5}$ \\
\hline $\mathrm{n}$ & 10 & 10 & 10 & 10 \\
Age $(\mathrm{yr})$ & $43 \pm 3$ & $44 \pm 3$ & $42 \pm 3$ & $43 \pm 2$ \\
Weight $(\mathrm{kg})$ & $55 \pm 3$ & $55 \pm 4$ & $55 \pm 7$ & $57 \pm 3$ \\
Duration of & & & & \\
surgery (min) & $96 \pm 10$ & $107 \pm 10$ & $107 \pm 10$ & $95 \pm 9$ \\
Blood loss $(\mathrm{ml})$ & $252 \pm 62$ & $263 \pm 60$ & $247 \pm 84$ & $250 \pm 70$ \\
\hline
\end{tabular}

There were no significant differences in four groups.

$($ Mean \pm SD $)$

TABLE II Side effects

\begin{tabular}{lllll}
\hline & Group C & Group IV & Group IT & Group $I T_{0.5}$ \\
\hline $\mathrm{N}$ & 10 & 10 & 10 & 10 \\
Respiratory & & & & \\
depression & 0 & 0 & 0 & 0 \\
Nausea & 2 & 1 & 1 & 1 \\
Vomiting & 0 & 1 & 0 & 0 \\
Pruritus & 0 & 1 & 1 & 1 \\
Hypotension & 0 & 0 & 0 & 0 \\
\hline
\end{tabular}

There were no significant differences in four groups

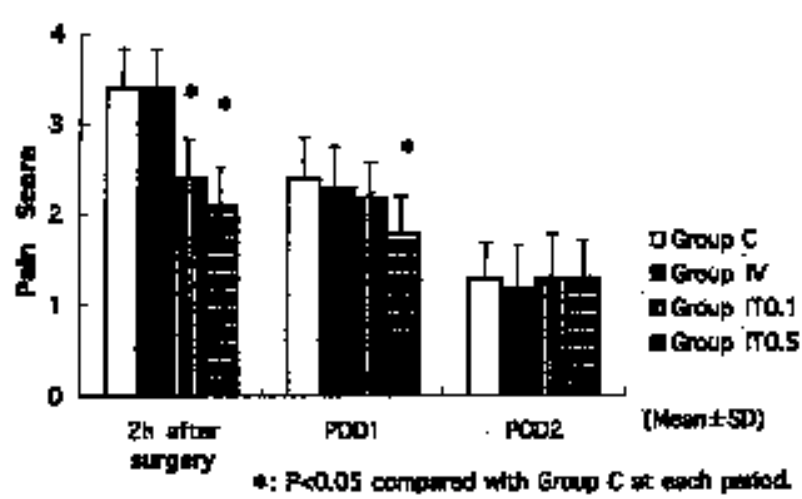

FIGURE 1 At two hours after surgery, pain scores in Groups ITO.5 and ITO.1 were lower than in Groups C and IV. On Postoperative day 1 , pain scores in Group ITO.5 were lower than in other groups.

Pain Score

0 : Pain free with movement or coughing

1: Minimal discomfort on movement or coughing

2: comfortable at rest, moderate pain on movement or coughing

3: Discomfort at rest, considerable pain with movement or coughing

4: Severe pain, even at rest

lower on postoperative day $1(23.9 \pm 8.4 \%)$ than before surgery $(45.7 \pm 13 \%)$, and returned to the baseline level on postoperative day 2 . In Group IT $_{0.5}$, the NK cell activity was lower on postoperative day 1 than in Groups $\mathrm{IT}_{0.1}, \mathrm{C}$ and IV. (Figure 2)

\section{Plasma adrenaline, noradrenaline and cortisol concen- trations}

There were no changes in plasma adrenaline or noradrenaline concentrations in all four groups. Cortisol concentration was higher two hours after surgery and on postoperative day 1 than baseline values in all four groups. In Groups $\mathrm{IT}_{0.5}, \mathrm{IT}_{0.1}$ and IV, it remained elevated on postoperative day 2. (Figure 3 )

The concentration of isoflurane for maintenance of anesthesia during surgery was lower in Group IT $_{0.5}$ and $\mathrm{IT}_{0.1}(0.82 \pm 0.3 \mathrm{MAC}$ of isoflurane $)$ than in the other two groups $(1.2 \pm 0.3 \mathrm{MAC}$ of isoflurane).

\section{Discussion}

In this study, we showed that intrathecal morphine suppressed NK cell activity in patients who underwent hysterectomy for uterine myoma. Surgical stress was relatively uniform in all patients and there were no differences in the duration of anesthesia and surgery among the four groups. Plasma adrenaline, noradrena- 


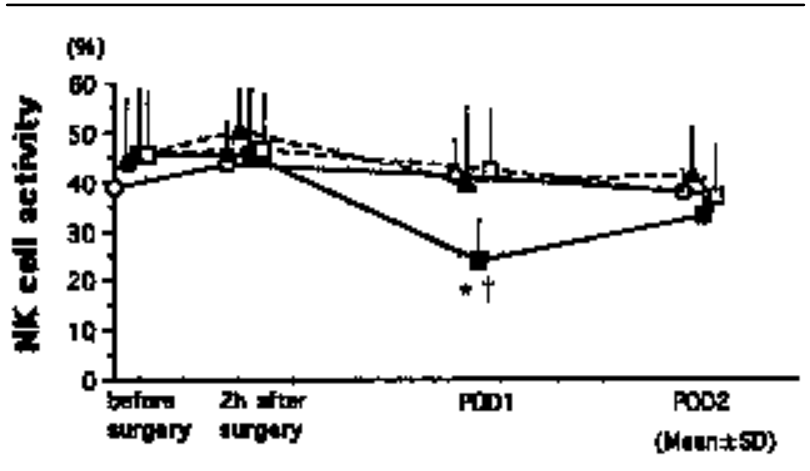

FIGURE 2 Natural killer cell activity, expressed as percentage cytotoxicity in Group C ( ), Group IV $(\boldsymbol{\Delta})$, Group ITO.I (, I) and Group ITO.5 (ם).

POD: postoperative day

*: $P<0.05$ compared with baseline values.

†: $P<0.05$ compared with Groups C, IV and ITO.1.

line and cortisol concentrations did not differ in the four groups, and no patient received blood transfusion. Pain score in Group IT $_{0.5}$ was lower than in Groups $\mathrm{IT}_{0.1}$ and IV one day following surgery. These data suggest that the main reason for the difference of NK cell activity among the morphine groups was dependent on the direct effect of the intrathecal administration of the higher dose of $0.5 \mathrm{mg}$ morphine.

Morphine has been reported to suppress NK cell activity $^{3,4}$ and several mechanisms have been proposed for immune suppression caused by opioids. ${ }^{5}$ First, opioids have an indirect effect on immune function through alterations in effector cell populations. For example, morphine pellet implantation in mice resulted in thymic and splenic atrophy with an increased ratio of CD4+/CD8+ cells, but decreased total number of both cell populations. ${ }^{6}$ Second, opioids can also act to suppress directly some components of the immune response such as the antibody response of splenocytes ${ }^{7}$ and rosette formation by lymphocytes. ${ }^{8}$ Third, opioids interact with suppressor cell populations or endogenous immune mediators. Fourth, opioids affect immune function by suppression of endogenous, tonic enhancement of effector cell activity. For example, endogenous opioids such as B-endorphin have been shown to stimulate immune effector cells in vitro. Finally, opioids can suppress immunity through effects on the central nervous system. For example, peripheral administration of $\mathrm{N}$-methylmorphine, which does not cross the blood-brain barrier, did not suppress NK cell activity, whereas, microinjections of $\mathrm{N}$-methylmorphine into the third ventricle of the brain suppressed NK cell activity. ${ }^{5}$ This effect was blocked by
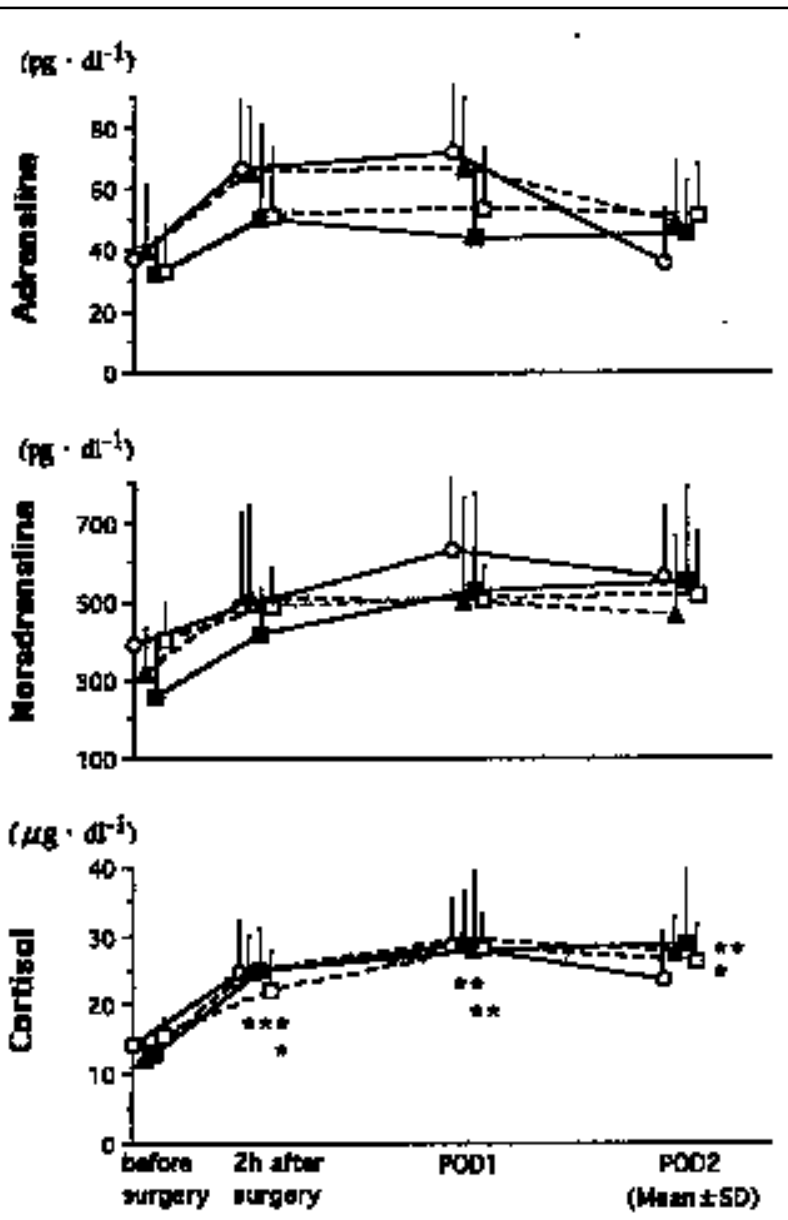

FIGURE 3 Changes of plasma adrenaline, noradrenaline and cortisol levels in Group C ( ), Group IV (A), Group ITO.1 (二) and Group ITO.5 (ם).

POD: postoperative day.

*: $P<0.05$ compared with baseline values in each group.

an opioid antagonist, naltrexone. After microinjection of 1 or $10 \mu \mathrm{g}$ morphine into the third ventricle, lymphocyte proliferative responses were decreased by 50 and $75 \%$, respectively, in rats. Similarly, a $50 \%$ decrease was observed after the microinjection of $1 \mu \mathrm{g}$ morphine into the anterior hypothalamus in rats. Morphine has also been shown to inhibit splenic NK cell activity after central administration in mice. These data implicate opioid receptors in the brain in morphine-induced suppression of NK cell cytotoxicity. Morphine might suppress NK cell activity by inducing or modulating the release of hormones. Intracerebroventricular-administered morphine has been shown to elevate plasma cortisol and catecholamines concentrations in rats. ${ }^{5}$ These cortisol and catecholamines could suppress NK cell activity by stimulating central sympathetic outflow. 
Despite these data implicating opioids as a cause of impaired immunity in vivo and in vitro, there are few data evaluating in vivo effects of opioids on human immunity. ${ }^{10}$ Our study evaluated the effects of morphine on NK cell activity in a clinical study, and indicated that intrathecal morphine suppress NK cell activity through effects on the central nervous system.

Surgical stress has been considered one of the causes that affect endocrine responses and suppress immune function, including NK cell activity. ${ }^{11}$ Endocrine responses caused by surgical stress, in particular a postoperative rise of cortisol, are reported to increase endogenous catecholamine reactions, leading to a decrease in NK cell activity. ${ }^{12}$ Pedersen et al., reported that both methylprednisolone and hydrocortisone produced dose-dependent suppression of NK cell activity. ${ }^{13}$ In the present study, cortisol was increased after surgery and on postoperative day $l$ in all four groups, however, the NK cell activity was not decreased in Group C. With effects of catecholamine on the NK cell activity, it has been reported that catecholamines suppressed immune function. ${ }^{14}$ Anatomical data indicate that the spleen is inverted by sympathetic nerve fibres that have access to lymphocytes and can modulate lymphocyte function. In this study, neither plasma adrenaline nor noradrenaline concentrations changed in all four groups.

Anesthesia itself has been reported to affect NK cell activity. ${ }^{12}$ However, Griffith et al., ${ }^{15}$ reported that neither halothane nor nitrous oxide affected NK cell activity at clinical concentrations. If inhalation anesthesia is used at high concentration or if the quantity of anesthetic used is increased as a result of operation, anesthetics alone may suppress NK cell activity. In order to maintain immunity at high levels, the doses or concentrations of anesthetics should be as low as possible. Intrathecal morphine allows the use of anesthetics at low concentrations to maintain anesthesia. ${ }^{16} \mathrm{In}$ fact, the concentration of the anesthetics for maintenance was lower in Group $\mathrm{IT}_{0.5}$ and $\mathrm{IT}_{0.1}$ than in the other two groups. In all four groups, the duration of surgery was short, and the bleeding was low. There was no decrease in NK cell activity in Group C. Consequently, the effects of anesthetics and surgical stress on NK activity was only slight in the present study.

In clinical practice, intrathecal doses of morphine ranging from 0.02 to $10 \mathrm{mg}$ have been used. ${ }^{17}$ From the present results, intrathecal morphine at a dose of $0.5 \mathrm{mg}$ and $0.1 \mathrm{mg}$ produced analgesia after surgery and at a dose of $0.5 \mathrm{mg}$ produced improved analgesia over the period from immediately after surgery to postoperative day 1, compared with Group C.

In vitro, morphine inhibition of lymphocyte proliferative responses occurs at concentrations that are two orders of magnitude greater than the plasma concentrations resulting from systemic administration, which suppress lymphocyte proliferation and produce analgesia in vitro. ${ }^{18}$ The $0.5 \mathrm{mg}$ and $0.1 \mathrm{mg}$ intrathecal doses used in this study cannot be regarded as equivalent to the $10 \mathrm{mg}$ intravenous dose for postoperative analgesia. The validity of a simple comparison of NK cell activity observed in Group $\mathrm{IT}_{0.5}$ and $\mathrm{IT}_{0.1}$ with that in Group IV is not certain. According to Hamra et al., ${ }^{19}$ subcutaneous morphine inhibited lymphocyte proliferation and altered phenotypic expression of cell surface markers, whereas equianalgesic doses of intrathecal morphine did not. Nelson et al. ${ }^{20}$ reported that morphine's immunologic and analgesic effects may be modulated by different mechanisms. Systemic morphine, which has potent supraspinal effects, but not intrathecal morphine, modulated lymphocyte function, providing further evidence that the immunomodulatory actions of morphine are centrally mediated. The lack of effect of spinally administered morphine suggests that spinal opioid receptors are not involved in morphine immunomodulation, and indicates a doseresponse relation at supraspinal opioid receptors. According to Bromage et al., ${ }^{2}$ morphine remains in the cerebrospinal fluid for a prolonged period because of its water-soluble property. Its prolonged retention in the central nervous system gives rise to its long-lasting effects. In our study, NK cell activity showed no changes in Groups C, IV and IT ${ }_{0.1}$, but NK cell activity was lower on postoperative day $\mathrm{l}$ in Group $\mathrm{IT}_{0.5}$. This suggests that the immunosuppressive effects of intrathecal morphine may be dose-dependent.

Morphine-induced side effects included nausea, pruritus and respiratory depression. Respiratory depression is a severe side effect, but none of the patients given intrathecal $0.5 \mathrm{mg}$ or $0.1 \mathrm{mg}$ morphine developed respiratory depression. Postoperative immune suppression may be a serious complication because patients who have undergone surgery are vulnerable to infection even in the absence of immune suppression. However, in the present study, postoperative infection did not occur in any group.

Intrathecal injection of $0.5 \mathrm{mg}$ morphine was useful for postoperative pain relief, but NK cell activity was suppressed on postoperative day 1 . The NK cell activity was not suppressed by intrathecal administration of $0.1 \mathrm{mg}$ or intravenous injection of $10 \mathrm{mg}$ morphine. These data suggest that intrathecal morphine is useful for the treatment of postoperative pain, but intrathecal morphine causes suppression of immunity in a dose-dependent manner. The mechanism of morphine suppression of NK cell activity may be through effects on the central nervous system. 
Acknowledgment

The authors gratefully acknowledges manuscript reviews by Professor Fumio Goto, Department of Anesthesiology and Reanimatology, Gunma University School of Medicine.

\section{References}

1 Wang JK, Nauss LA, Thomas JE. Pain relief by intrathecally applied morphine in man. Anesthesiology 1979; 50: 149-51.

2 Shvit $\Upsilon$, Depaulis A, Martin FC, et al. Involvement of brain opiate receptors in the immune-suppressive effect of morphine. Neurobiology 1986; 83: 7114-7.

3 Yeager MP, Colacchio TA, Yu CT, et al. Morphine inhibits spontaneous and cytokine-enhanced natural killer cell cytotoxity in volunteers. Anesthesiology 1995; 83: 500-8.

4 Bryant HU, Bernton EW, Kenner JR, Holaday JW. Role of adrenal cortical activation in the immunosuppressive effects of chronic morphine treatment. Endocrinology 1991; 128: 3253-8.

5 Hernandez MC, Flores LR, Bayer BM. Immunosuppression by morphine is mediated by central pathways. J Pharmacol Exp Ther 1993; 267: 1336-41.

6 Arora PK, Fride E, Petitto J, Waggie K, Skolnick P. Morphine-induced immune alterations in vivo. Cell Immunol 1990; 126: 343-53.

7 Bussiere JL, Taub DD, Meissler JJ Jr, Adler MW, Rogers TJ, Eisenstein TK. Effects of opioids on murine antibody responses. Advances in the Biosciences 1993; 86: 563-72.

8 Wybran J, Appleboom T, Famaey J-P, Govaerts A. Suggestive evidence for receptors for morphine and methionine-enkephalin on normal human blood $\mathrm{T}$ lymphocytes. J Immunol 1979; 123: 1068-70.

9 Mandler RN, Biddison WE, Mandler R, Serrate SA. Bendorphin augments the cytolytic activity and interferon production of natural killer cells. J Immunol 1986; 136: 934-9.

10 Kutza J, Gratz I, Afshar M, Murasko DM. The effects of general anesthesia and surgery on basal and interferon stimulated natural killer cell activity of humans. Anesth Analg 1997; 85: 918-23.

11 Slade MS, Simmons RL, Yunis E, Greenberg LJ. Immunosupression after major surgery in normal patients. Surgery 1975; 78: 363-72.

12 Walton $B$. Effect of anaesthesia and surgery on immune status. Br J Anaesth 1979; 51: 37-43.

13 Pedersen BK, Beyer JM. Charactarization of the in vitro effects of glucocorticoids on NK cell activity. Allergy 1986; 41: 220-4.
14 Heilig M, Irwin M, Grewal I, Sercarz E. Sympathetic regulation of T-helper cell function. Brain Behav Immun 1993; 7: 154-63.

15 Griffith CDM, Kamath MB. Effect of halothane and nitrous oxide anaesthesia on natural killer lymphocytes from patients with benign and malignant breast disease. Br J Anaesth 1986; 58: 540-3.

16 Drasner K, Bernards CM, Ozanne GM. Intrathecal morphine reduces the minimum alveolar concentration of halothane in humans. Anesthesiogy 1988; 69: 310-2.

17 Samii K, Chamvin M, Viars P. Postoperative spinal analgesia with morphine. Br J Anaesth 1981; 53: 817-20.

18 Bayer BM, Gastongray MR, Hernandez $M C$.

Distinction between the in vitro and in vivo inhibitory effects of morphine on lymphocyte proliferation based on agonist sensitivity and naltrexone reversibility. Immunopharmacology 1992; 23: 117-24.

19 Hamra JG, Yaksh TL. Equianalgesic doses of subcutaneous but not intrathecal morphine alter phenotypic expression of cell surface markers and mitogen-induced proliferation in rat lymphocytes. Anesthesiology 1996; 85: 355-65.

20 Nelson CJ, Dykstra LA, Lysle DT. Comparison of the time course of morphine's analgesic and immunologic effects. Anesth Analg 1997; 85: 620-6.

21 Bromage PR, Camporesi EM, Durant PAC, Nielsen $\mathrm{CH}$. Nonrespiratory side effects of epidural morphine. Anesth Analg 1982; 61: 490-4. 